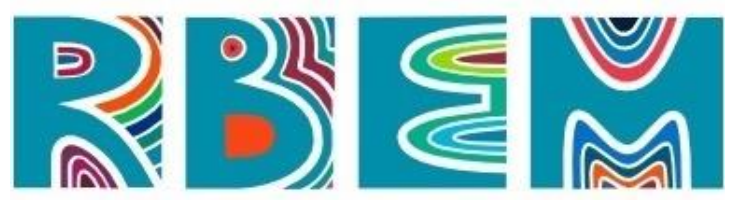

REVISTA BAIANA dE EDUCAÇÃo MATEMÁtICA

ARTIGO https://doi.org/10.47207/rbem.v2i01.12765

\title{
O Estágio Curricular Supervisionado e o Ensino Remoto: percepções de futuros professores de matemática
}

\author{
BRAGA, Maria Dalvirene \\ Universidade de Brasília (UnB). Mestre em Educação pela UnB. ORCID: https://orcid.org/0000-0003-0948- \\ 8228. E-mail: dalvirenebraga@gmail.com.
}

PINA NEVES, Regina da Silva

Universidade de Brasília (UnB). Doutora em Psicologia pela UnB. ORCID https://orcid.org/0000-0002-79529665. E-mail: reginapina@gmail.com.

MENDONÇA, Marlene Pereira do Nascimento

Secretaria de Estado de Educação do Distrito Federal. Especialista em Metodologias do Ensino de Matemática. ORCID: https://orcid.org/0000-0002-2539-8380. E-mail: profmarlenemendonca@gmail.com.

OLIVEIRA, Camila Fernandes Beserra de

Universidade de Brasília (UnB). Licencianda em Matemática pela UnB. ORCID: https://orcid.org/0000-00026614-1864. E-mail: camisfernandesoliveira@gmail.com.

Resumo: Este artigo tem como objetivo compreender as percepções de futuros professores sobre o

Estágio Curricular Supervisionado em Matemática (ECSM) vivenciado por eles em situação de Ensino Remoto Emergencial (ERE). O estudo, de natureza qualitativa, foi realizado no contexto da disciplina de ECSM no período de março a junho de 2021 e integrou duas professoras orientadoras, uma professora supervisora, 20 futuros professores, sendo 16 homens e quatro mulheres em trabalho semanal de oito horas, alternando encontros síncronos e assíncronos. Os dados foram construídos por meio de dois instrumentos: 1) questionário on-line a partir do Google forms, composto de 15 perguntas entre fechadas e abertas e, 2) relatórios finais - escrita descritiva e reflexiva produzida pelos futuros professores ao longo do percurso formativo. Posteriormente, eles foram tratados em aproximação aos pressupostos da análise de conteúdo Bardin (2016) e Franco (2018), o que permitiu reunir suas percepções quanto às condições físicas e tecnológicas da oferta da disciplina bem como às singularidades didático-pedagógicas de seu desenvolvimento. Os resultados mostram que os futuros professores vivenciaram condições tecnológicas favoráveis à realização do ECSM; apresentaram percepções divergentes quanto ao ERE e suas demandas por novos recursos tecnológicos, variados estilos de comunicação e interação entre professores e estudantes; percepções convergentes sobre a pertinência do percurso formativo vivenciado por eles e a necessidade de se promover, sempre, equidade tanto no ensino superior quanto na educação básica seja na pandemia, seja pós-pandemia.

Palavras-chave: Estágio Curricular em Matemática. Ensino Remoto. Ensino Médio.

\section{Supervised Curriculum Internship and Remote Teaching: Perceptions of Future Mathematics Teachers}

Abstract: This article aims to understand the perceptions of future professors about Supervised Curricular Internship in Mathematics (SCIM) experienced by them in Emergency Remote Teaching 


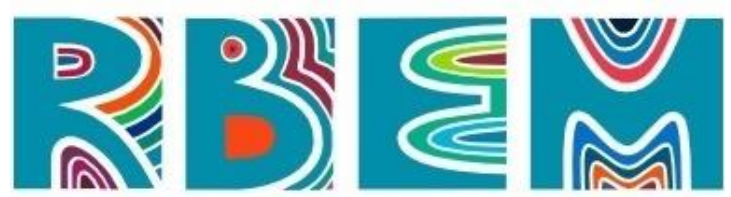

REVISTA BAIANA DE EDUCAÇÃO MATEMÁTICA

(ERT) situation. The study, of a qualitative nature was carried out in the context of the SCIM discipline from March to June 2021 and included two advisor professors, one supervisory teacher, twenty future professors, sixteen men and four women working eight hours a week, alternating synchronous and asynchronous encounters. Data were built using two tools: 1) online questionnaire from Google forms, composed of fifteen open and closed questions, and 2) final reports - descriptive and reflective writing produced by future professors along the training path. Subsequently, they were treated in an approximation with the assumptions of Bardin (2016) and Franco (2018) content analysis, which allowed us to gather their perceptions about the physical and technological conditions of the discipline's offer as well as the didactic-pedagogical singularities of its development. The results show that future professors experienced favorable technological conditions for carrying out the SCIM; presented diverging perceptions about the ERT and its demands for new technological resources, varied styles of communication and interaction between professors and students; converging perceptions about the relevance of the training path experienced by them and the need to always promote equity both in higher education and in basic education, whether in the pandemic or post-pandemic.

Keywords: Curricular Internship in Mathematics. Remote Teaching. High School.

\title{
Pasantía de currículo supervisado y enseñanza remota: percepciones de futuros profesores de matemáticas
}

\begin{abstract}
Resumen: Este artículo tiene como objetivo comprender las percepciones de los futuros docentes sobre la Pasantía de Currículo Supervisado en Matemáticas (ECSM) vivida por ellos en situaciones de Emergencia de Enseñanza Remota (ERE). El estudio, de carácter cualitativo, se llevó a cabo en el contexto de la disciplina ECSM de marzo a junio de 2021 e incluyó a dos profesores orientadores, un profesor supervisor, 20 futuros profesores, 16 hombres y cuatro mujeres trabajando ocho horas semanales, alternando sincrónicamente. y encuentros asincrónicos. Los datos se construyeron utilizando dos instrumentos: 1) cuestionario en línea de los formularios de Google, que consta de 15 preguntas cerradas y abiertas, y 2) informes finales - escritura descriptiva y reflexiva producida por los futuros profesores a lo largo de la ruta de formación. Posteriormente, fueron tratados de forma aproximada con los supuestos de análisis de contenido de Bardin (2016) y Franco (2018), lo que les permitió recoger sus percepciones sobre las condiciones físicas y tecnológicas de la oferta de la disciplina, así como las singularidades didáctico-pedagógicas de su desarrollo. Los resultados muestran que los futuros docentes experimentaron condiciones tecnológicas favorables para la realización del ECSM; presentó percepciones divergentes sobre el ERE y sus demandas de nuevos recursos tecnológicos, variados estilos de comunicación e interacción entre docentes y estudiantes; percepciones convergentes sobre la relevancia de la trayectoria formativa vivida por ellos y la necesidad de promover siempre la equidad tanto en la educación superior como en la educación básica, ya sea en la pandemia o después de la pandemia.
\end{abstract}

Palabras clave: Prácticas Curriculares en Matemáticas. Enseñanza remota. Escuela secundaria.

\section{Introdução}

As comunidades escolar e universitária no Brasil têm vivenciado inúmeras mudanças, desde março de 2020, em função da pandemia causada pelo vírus SARScoV2. Nesse 


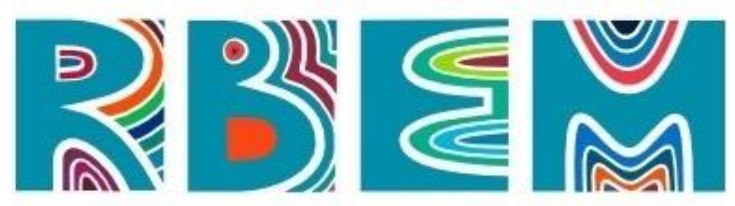

REVISTA BAIANA DE EDUCAÇÃO MATEMÁTICA

contexto, o acesso à educação e a interação entre professores e estudantes, formadores e futuros professores têm sido, constantemente, modificada face ao Ensino Remoto Emergencial $^{1}$ (ERE) e suas demandas em termos de recursos tecnológicos e abordagens didáticas. Ademais, agregam-se as situações de exclusão devido às desigualdades sociais e econômicas, ampliando o número de estudantes que não frequentam e/ou acompanham as aulas virtuais por falta de equipamentos, pela baixa qualidade na conexão de internet, por falta de apoio à aprendizagem escolar, entre outros. Logo, ensinar e aprender na educação básica e no ensino superior em ambientes virtuais tornou-se um desafio, cotidiano, para os profissionais da educação.

Ciente de tudo isso, a Universidade de Brasília desenvolveu um plano de retomada das aulas, atenta às necessidades da comunidade universitária, especialmente, dos estudantes assistidos por programas de vulnerabilidade social, o que se efetivou em agosto de 2020, por meio de aulas síncronas e assíncronas a partir de ferramentas como: zoom, meet, moodle, etc. No bojo dessas mudanças, a disciplina de Estágio Curricular Supervisionado em Matemática (ECSM) foi desafiada a se (re)inventar, a ser desenvolvida em encontros virtuais entre professores orientadores, professores supervisores e futuros professores; estudantes da educação básica e futuros professores, os quais demandavam novos modos de comunicação e interação.

Tudo isso reverberou na construção de um percurso formativo que buscou ampliar os vínculos entre a universidade/escola e a interação entre professores orientadores, supervisores e futuros professores em ações de estudo, observação, colaboração, planejamento e regência em matemática no ERE. Desse modo, integraram a disciplina de Estágio Curricular Supervisionado em Matemática (ECSM) referente ao segundo semestre letivo de 2020, ofertada de março a junho de 2021, duas professoras orientadoras, uma professora supervisora (três das autoras deste texto), 20 futuros professores, sendo 16 homens e quatro mulheres (uma delas autora deste texto) em oito horas de trabalho semanal, alternando encontros síncronos e assíncronos.

\footnotetext{
${ }^{1}$ Um conjunto de estratégias didáticas e pedagógicas que visam diminuir os impactos na aprendizagem em vista da situação de pandemia. É assim considerado por causa do impedimento de alunos e professores em frequentar as instituições de ensino via decreto, e emergencial porque o planejamento anual foi temporariamente suspenso (BRAGA et al, 2021, p.3).
} 


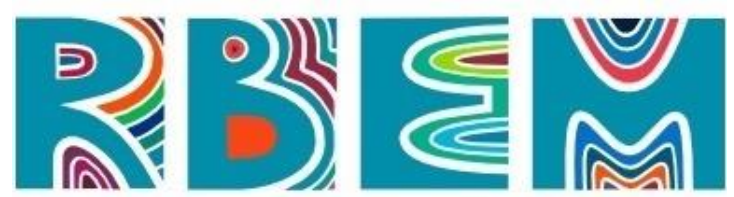

REVISTA BAIANA DE EDUCAÇÃO MATEMÁTICA

Neste artigo, descrevemos as diferentes ações que possibilitaram seu desenvolvimento tendo como objetivo compreender as percepções dos futuros professores sobre o ECSM vivenciado por eles no contexto do ERE. Em termos de organização textual, optamos por discutir o papel do ECSM na formação inicial do(a) professor(a) de matemática, posteriormente, descrevemos as características do ECSM em situação de ERE e suas singularidades didático-pedagógicas. Em seguida, apresentamos o estudo em si por meio da descrição dos participantes, instrumentos e modos de organização dos dados. Por fim, discutimos as percepções dos futuros professores a respeito do ECSM.

\section{O Estágio Curricular Supervisionado em Matemática (ECSM) e a formação docente}

Discussões, reflexões e partilhas de experiências sobre o estágio e características de seu desenvolvimento nos cursos de licenciatura em pedagogia e matemática são recorrentes na literatura em Educação e em Educação Matemática constituindo um amplo campo de estudo. Pimenta e Lima (2012), por exemplo, o descrevem "como um campo de conhecimento próprio e um método investigativo que envolve a reflexão e a intervenção na vida das escolas, dos professores, dos alunos e da sociedade na qual estão inseridos" (p. 26). Em continuidade, as autoras advertem que "considerar o estágio como campo de conhecimento significa atribuir-lhe um estatuto epistemológico que supere sua tradicional redução à atividade prática instrumental" (PIMENTA e LIMA, 2012, p. 29).

Estes entendimentos são reafirmados por outros pesquisadores que destacam este componente obrigatório da formação inicial dos futuros professores como espaço singular para o desenvolvimento de aprendizagens sobre a educação escolar e a docência, promovendo compreensões sobre a complexidade das práticas docentes e das instituições de ensino (TEIXEIRA; CYRINO, 2013; GATTI, 2014; BARBOSA; LOPES, 2021), sendo, portanto, "um momento especial do processo de formação do professor em que ocorre de maneira mais efetiva a transição ou a passagem de aluno a professor" (FIORENTINI; CASTRO, 2003, p. 122).

Nesse sentido, Teixeira e Cyrino (2015) destacam, por exemplo, o valor das orientações de estágio, visto que a partir delas "os futuros professores 


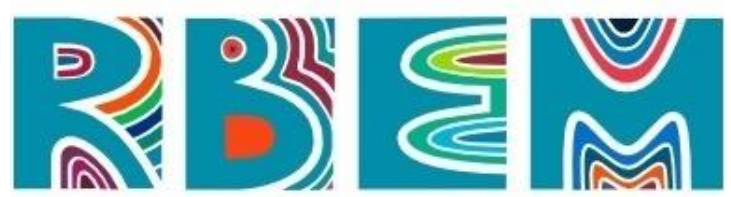

REVISTA BAIANA DE EDUCAÇÃO MATEMÁTICA

mobilizam/desenvolvem elementos relacionados à identidade profissional” (p. 658). Já Lopes et al. (2017) destacam a ampliação da pesquisa sobre o tema e apontam:

a possibilidade de diferentes metodologias e modos de organizar e de desenvolver o Estágio; a compreensão do espaço de aprendizagem da docência que pode ser constituído nesse momento de graduação; o movimento de reflexão e construção de saberes docentes para futuros professores de matemática; e, ainda, a oportunidade de construir a identidade profissional a partir do Estágio Curricular Supervisionado e não somente quando efetivamente se tornar professor, após o curso de licenciatura (LOPES et al., 2017, p. 89).

Os autores destacam, ainda, a importância de construir espaços formativos que possibilitem ao futuro professor de matemática "uma prática reflexiva e que leve à construção de diferentes saberes, em especial o conhecimento pedagógico ou didático do conteúdo" (p. 88) e o entendimento do ECSM "como um espaço em que teoria e prática não se dissociam; em que, principalmente, ocorrem aproximação e interação com a educação básica" (LOPES et al., 2017, p. 88).

Entretanto, nossa experiência como formadoras em cursos de Licenciatura em Matemática mostra-nos a complexidade de se constituir o ECSM sob tais prerrogativas. Alguns estudos ajudam-nos a compreender essa complexidade quanto mostram as situações de fragilidade e de insucesso que ainda perduram em muitos cursos sejam em instituições públicas ou privadas, como bem discutem Gatti e Barreto (2009) em função de seu esvaziamento nos Projetos Pedagógicos de Curso e/ou falta de definição do seu modo de desenvolvimento (DINIZ PEREIRA, 2007). Apesar das dificuldades, é crescente o número de estudos que apresentam experiências exitosas em ECSM, especialmente, em contextos nos quais os responsáveis pela disciplina construíram processos formativos em diálogo com a escola, os professores supervisores, os futuros professores, respeitando as necessidades do próprio curso de formação inicial e seu papel social na comunidade (BARBOSA; LOPES, 2021). Tudo isso, mostra-nos que caminhos de mudança têm sido trilhados com êxito e mostram que é possível conceber, desenvolver e avaliar o ESCM de modo a romper com a visão do professor como um técnico, buscando, por sua vez, alterar as concepções de atividade docente, de formação e de estágio, apoiando-as na epistemologia da práxis. 


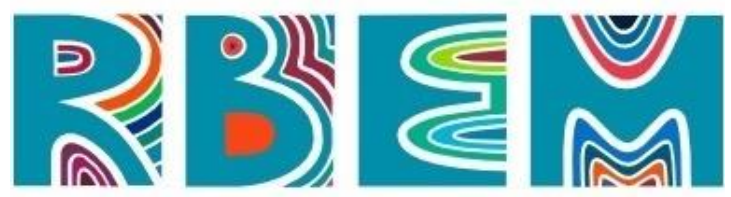

REVISTA BAIANA DE EDUCAÇÃO MATEMÁTICA

[...] por muito tempo considerado a hora da prática, o estágio passa a ser considerado como aproximação da realidade; como uma atividade teórica instrumentalizadora da práxis; como construção do conhecimento pedagógico que traz o estágio com pesquisa e como pesquisa. Essa trajetória conceitual leva o estágio a ocupar espaço central na formação inicial universitária do professor (DAUANNY; LIMA; PIMENTA, 2019, p. 15, grifo nosso).

Logo, evidencia-se a necessidade de organizar, coordenar, vivenciar e avaliar percursos formativos que integrem o futuro professor no cotidiano da escola, que ampliem o vínculo universidade/escola, professor orientador/professor supervisor, futuro professor/professor experiente, futuro professor/estudantes e que nesse processo ele desenvolva e/ou aperfeiçoe as aprendizagens necessárias para o exercício da docência.

Por conseguinte, tem crescido o número de cursos de Licenciatura em Matemática que por meio de grupos de formadores de professores buscam reestruturar o ECSM, atentos às crenças, percepções, concepções, valores e interesses de futuros professores, formadores, egressos, coordenadores, entre outros sujeitos que integram a prática formativa (PROENÇA, 2012). De modo especial, a compreensão da percepção de futuros professores entendida "como o processo cognitivo da consciência que consiste no reconhecimento, interpretação e significação para a elaboração de julgamentos em torno das sensações obtidas do ambiente físico e social" (MELGAREJO VARGAS, 1994, p. 48) tem sido determinante nesses processos de reestruturação por revelar como eles interpretam a experiência, atribuindo significado a ela. Assim, temos buscado construir um percurso formativo no qual o futuro professor vivencia sua futura prática profissional de forma reflexiva e colaborativa por meio de trocas de experiências e diálogo entre professores orientadores e supervisores. E, ao mesmo tempo, compreender as percepções dos futuros professores sobre o percurso vivido, buscando aperfeiçoá-lo, constantemente.

\section{O Estágio Curricular Supervisionado em Matemática (ECSM) da Universidade de}

\section{Brasília (UnB): características de seu desenvolvimento}

Em 2020, desenvolvemos o ECSM em situação de ensino remoto tanto na universidade quanto na escola. Nessas condições, a disciplina integrou 20 estagiários, sendo 16 do sexo masculino e quatro do sexto feminino, com idades entre 22 e 30, sendo, a maioria, 


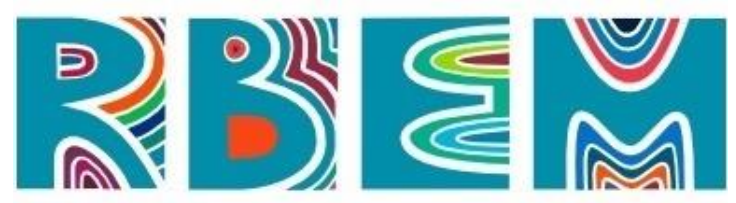

REVISTA BAIANA DE EDUCAÇÃO MATEMÁTICA

com 24 anos e foi desenvolvida por meio de encontros semanais síncronos de duas horas de duração, em média, via plataforma Zoom, os quais promoveram o acesso aos documentos curriculares, aos livros didáticos adotados na escola, a artigos científicos, entre outros materiais, assim como, o diálogo constante entre professora orientadora/ estagiários acerca dos significados que eles atribuíam à experiência de estagiar nessas condições. Ademais, os estagiários desenvolviam duas horas de trabalho em modo assíncrono para o desenvolvimento das etapas 2 e 7 , sempre em contato com a professora orientadora. A figura (1) seguinte ilustra um destes encontros do mesmo modo que o quadro 1 descreve parte das ações empreendidas.

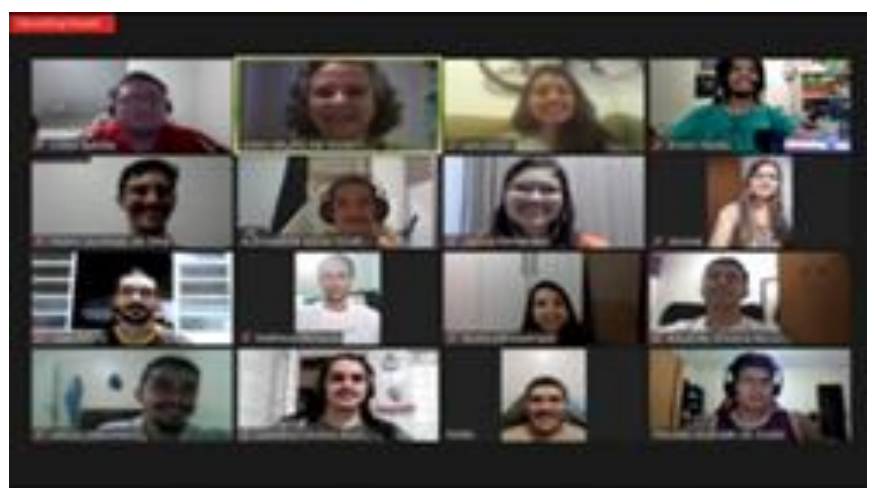

Figura 1: Registro dos participantes no encontro síncrono 12 na plataforma Zoom (RELATÓRIO DE PESQUISA)

\begin{tabular}{|l|l|c|}
\hline Encontro & \multicolumn{1}{|c|}{ Açães } & Duração \\
\hline Encontro 6 & $\begin{array}{l}\text { Os grupos trabalharam fora do ambiente da plataforma zoom na elaboração e resolução de } \\
\text { um exercício, um problema e /ou uma situação de exploração) com base no texto discutido } \\
\text { na aula 5. Para essa ação foi disponibilizado todo o horário previsto para a disciplina (4h). Os } \\
\text { grupos ficaram livres para se reunirem em outros dias e horários. }\end{array}$ & $4 \mathrm{~h}$ \\
\hline Encontro 7 & $\begin{array}{l}\text { Cada membro dos grupos trabalhou fora do ambiente da plataforma zoom para a elaboração } \\
\text { do vídeo de uma aula a partir do exercício, problema e /ou situação de exploração da aula } \\
\text { anterior. }\end{array}$ & $4 \mathrm{~h}$ \\
\hline \multirow{2}{*}{$\begin{array}{l}\text { Acolhida e esclarecimentos sobre o fechamento da primeira nota da disciplina; } \\
01 / 04 / 2021\end{array}$} & $\begin{array}{l}\text { Retorno em relação à avaliação das ações realizadas pelos estagiários nas aulas anteriores; } \\
\text { Relato dos estagiários a respeito da experiência de realizar as ações; }\end{array}$ & \\
& $\begin{array}{l}\text { Relato dos estagiários sobre o estágio na escola (documentação, observação); } \\
\text { Apresentação de um cronograma para realização do estágio na escola; } \\
\text { Ações para próxima aula: leitura e exploração do template do planejamento. }\end{array}$ & $2 \mathrm{~h}$ \\
\end{tabular}

Quadro 1 - Descrição de parte dos encontros realizados entre professora orientadora e futuros professores (RELATÓRIO DE PESQUISA, 2021).

Igualmente, os estagiários mantiveram contato semanal com a professora supervisora por meio Google Classroom, Google Meet e WhatsApp para a realização das ações de 


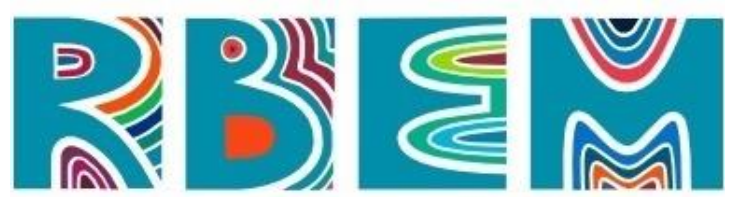

REVISTA BAIANA DE EDUCAÇÃO MATEMÁTICA

observação, colaboração e regência, sendo possível, assim, acompanhar os modos utilizados por ela para adaptar/recriar sua prática didática ao contexto do ensino remoto em momentos síncronos e assíncronos ${ }^{2}$. Sabíamos que a realidade dos estudantes de ensino médio muitas vezes não era favorável para a comunicação síncrona, pois esta depende de computadores, celulares ou tablets e uma conexão de internet estável. Por isso, os momentos assíncronos foram mais viáveis, porém ambos ocorreram com o intuito de ampliar as oportunidades de aprendizagem. Além disso, estivemos atentas à realidade da escola na qual cada turma tinha uma sala virtual no Google Classroom, onde os professores colocavam os avisos e as atividades assíncronas, que também eram entregues pela mesma plataforma. Já o Google Meet era usado para as aulas síncronas. Para alcançar os estudantes que não possuíam nenhuma forma de acesso a essas plataformas, a professora supervisora preparava materiais impressos sobre os conteúdos e disponibiliza na escola para que eles tivessem acesso ao mesmo conteúdo que os outros estavam tendo no modo online.

O quadro 2, a seguir, reúne informações sobre alguns encontros e o modo como eles foram desenvolvidos.

\begin{tabular}{|c|c|c|c|c|}
\hline Encontro & Ação & Tipologia da aula & Ações & Duração \\
\hline 23/03/2021 & Observação & Síncrona & $\begin{array}{l}\text { Observação de aula síncrona destinada aos alunos de oito } \\
\text { turmas do } 3^{\circ} \text { ano do ensino médio na plataforma Google } \\
\text { Meet. }\end{array}$ & $45 \mathrm{~min}$ \\
\hline \multirow[t]{2}{*}{ 01/04/2021 } & \multirow[t]{2}{*}{ Observação } & Síncrona & $\begin{array}{l}\text { Observação de aula síncrona destinada aos alunos de oito } \\
\text { turmas do } 3^{\circ} \text { ano do ensino médio na plataforma Google } \\
\text { Meet. }\end{array}$ & $45 \mathrm{~min}$ \\
\hline & & Assíncrona & $\begin{array}{l}\text { Observação de atividades postadas na plataforma Google } \\
\text { Classroom pela professora regente. }\end{array}$ & Livre \\
\hline \multirow[b]{2}{*}{$15 / 04 / 2021$} & \multirow[b]{2}{*}{ Participação } & Síncrona & Interação do grupo 1 de estagiários com os alunos no chat. & $45 \mathrm{~min}$ \\
\hline & & Assíncrona & $\begin{array}{l}\text { *Elaboração de um formulário Google Forms (pelo grupo 1) } \\
\text { sobre o conteúdo "princípio fundamental de contagem". } \\
\text { *Postagem na plataforma Google Classroom para acesso } \\
\text { dos alunos. }\end{array}$ & Livre \\
\hline \multirow[b]{2}{*}{$04 / 05 / 2021$} & \multirow[b]{2}{*}{ Regência } & Síncrona & Aula do grupo 1 na plataforma Google Meet & $45 \mathrm{~min}$ \\
\hline & & Assíncrona & $\begin{array}{l}\text { Leitura e análise de atividades postadas na plataforma } \\
\text { Google Classroom pelos grupos de estagiários e pela } \\
\text { professora regente. }\end{array}$ & Livre \\
\hline
\end{tabular}

Quadro 2: Descrição de parte dos encontros realizados entre professora supervisora, futuros professores e estudantes do ensino médio (RELATÓRIO DE PESQUISA, 2021).

Assim, ao vivenciarem o ECSM em situação de ERE, os futuros professores

\footnotetext{
${ }^{2}$ Comunicação assíncrona: ocorre de modo diferido, não sincronizado, não exige a presença simultânea dos participantes, nem no espaço nem no tempo, para comunicarem entre si. Comunicação síncrona: ocorre de forma sincronizada, implica que os participantes se encontrem num mesmo espaço (físico ou online) e em tempo real, para comunicarem entre si (MOREIRA, HENRIQUES E BARROS, 2020, p. 2).
} 


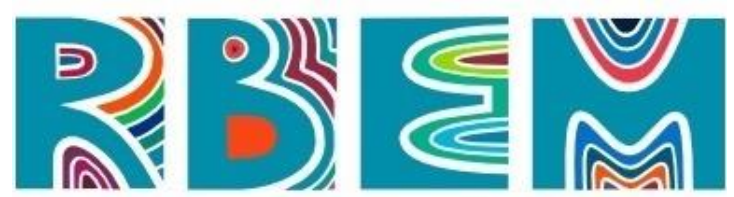

REVISTA BAIANA DE EDUCAÇÃO MATEMÁTICA

interagiram com espaços, problemas, limitações e possibilidades do exercício da docência em matemática no ensino médio. Assim, tiveram a oportunidade de estudar, planejar, simular, analisar, ensinar e aprender a profissão docente. Ao longo de todo este percurso formativo, os futuros professores construíram, também, percepções acerca da experiência que precisam ser conhecidas pelas professoras orientadoras, supervisoras e, posteriormente, utilizadas para aperfeiçoar o percurso formativo. Desse modo, intentamos neste estudo compreender as percepções dos futuros professores que cursaram o ECSM nas condições descritas, em especial, como percebem sua oferta em ERE e suas contribuições para a formação profissional (TEIXEIRA; CYRINO, 2013).

\section{O estudo}

O estudo pautou-se em pressupostos da abordagem qualitativa escutando os futuros professores com o intuito de compreender suas percepções sobre o ECSM vivenciado por eles. Como sabemos, nessa tipologia de abordagem busca-se "compreensão dos significados e características situacionais apresentadas pelos entrevistados, em lugar da produção de medidas quantitativas de características ou comportamentos (RICHARDSON et. al, 2017, p. 90)". Participaram da pesquisa 20 futuros professores que cursaram a disciplina de ECSM com prática no ensino médio, descrita anteriormente, sendo $12 \mathrm{em}$ seu último semestre de curso. Destes, 16 eram do sexo masculino e quatro do sexo feminino, com idades entre 22 e 30, sendo, a maioria, com 24 anos. Estes atuaram como estagiários, no ERE, em uma escola pública da Secretaria de Estado de Educação do Distrito Federal (SEEDF) da região administração de Ceilândia, no DF, em oito turmas do terceiro ano do ensino médio, com uma média de 40 alunos por turma numa faixa etária superior a 15 anos.

A coleta de dados aconteceu por meio de dois instrumentos: 1) Questionário online a partir do Google forms, composto de 15 perguntas entre fechadas e abertas, algumas com opções de justificativa e outras com a possibilidade de marcar mais de uma opção ou alternativa, ressaltando as condições de oferta e o processo formativo. Assim, intentava-se "o conhecimento de opiniões, percepções, crenças, sentimentos, interesses, expectativas, situações vivenciadas, etc" (GIL 2019, p. 128); e 2) Relatórios Finais - escrita descritiva e reflexiva produzida pelos futuros professores ao longo do percurso formativo. 


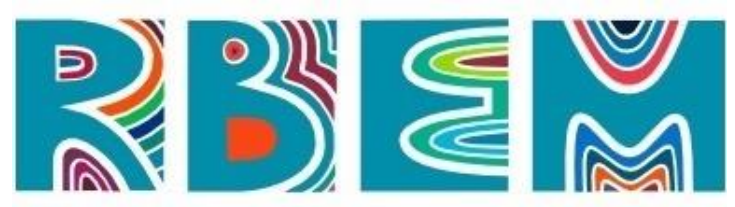

REVISTA BAIANA DE EDUCAÇÃO MATEMÁTICA

Para a análise dos dados, foram realizadas tabulações e inferências possíveis com base nas ideias de Franco (2018) e Bardin (2016). As respostas dos futuros professores foram organizadas e lidas individualmente e coletivamente pelas autoras visto que "os resultados brutos são tratados de maneira a serem significativos (falantes) e válidos” (BARDIN, 2016, p. 101). Isso conduziu-nos à elaboração de quadros-síntese que permitiram a elucidação das "falas" carregadas de "afetivos e emocionais" (FRANCO, 2018, p. 43). Neste artigo, trabalhamos parte dessas "falas", extraindo delas elementos de significado, o que possibilitou organizá-las em: percepções dos futuros professores quanto às condições físicas e tecnológicas e percepções dos futuros professores quanto ao ECSM.

\section{Apresentação e discussão dos resultados}

\section{Percepções dos futuros professores quanto às condições físicas e tecnológicas}

Inicialmente, as questões versavam sob quais condições os futuros professores 10 cursaram a disciplina, em especial, informações sobre o acesso à internet e à qualidade dos espaços físicos que dispunham para os estudos. Sobre o acesso à internet, foi questionado EDUCACÁO
MATEMATICA como eles o classificavam com uma pergunta em escala linear, onde um (1) significava ruim e cinco (5) significava ótimo. As respostas mostram que a maioria optou pelos marcadores 5 e 4, indicando qualidade de acesso à internet. Para saber mais sobre como eles acessaram a internet e como era o seu ambiente de estudo foram feitas três perguntas por meio de caixa de seleção, onde eles poderiam marcar mais de uma resposta. A primeira delas foi "Qual desses dispositivos você possui?", que apresentava as opções "Computador de mesa", "Notebook", Celular/Smartphone", "Tablet" e "Outros". 


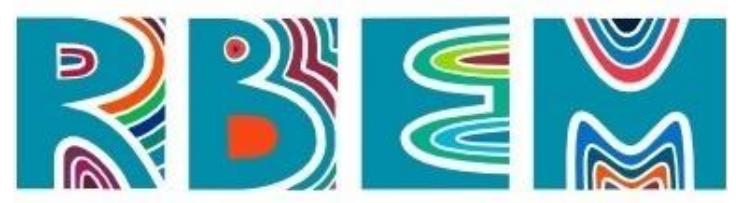

REVISTA BAIANA DE EDUCAÇÃO MATEMÁTICA

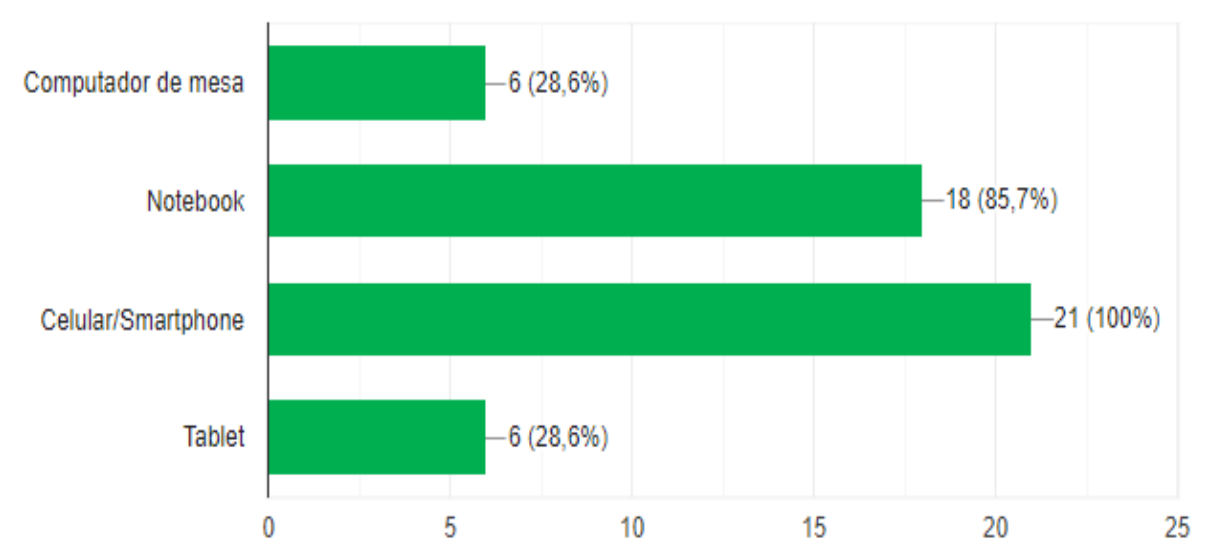

Gráfico 1 - Dispositivos que os estudantes possuíam (ARQUIVO DOS AUTORES, 2021)

A segunda questão versava sobre quais equipamentos eram compartilhados na casa do futuro professor, tendo as mesmas opções de resposta da pergunta anterior, recebendo somente 11 respostas.
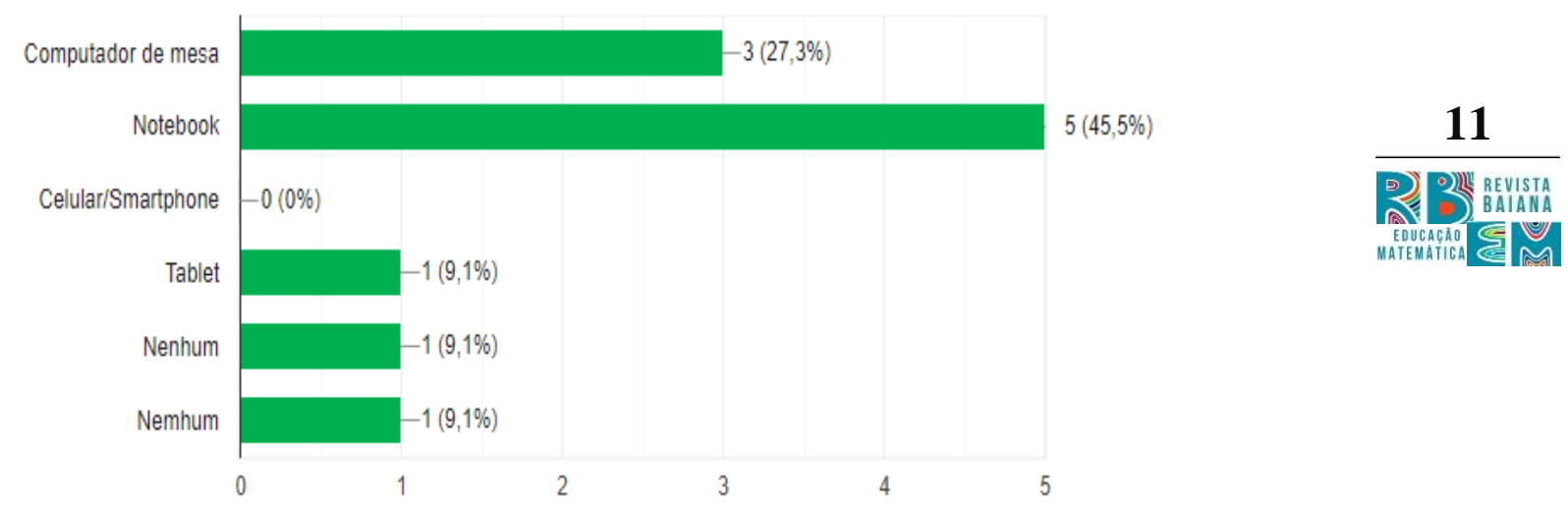

Gráfico 2 - Equipamentos compartilhados (ARQUIVO DOS AUTORES, 2021)

Ao serem questionados sobre o local de estudo na maior parte das vezes, tendo como opções de resposta "Estudo no quarto individual", "Estudo no quarto compartilhado com outro (a)", "Estudo na sala", "Estudo na cozinha", "Estudo onde tem espaço (na sala, cozinha, outros.)", "Tenho um lugar próprio para estudo" e "No entanto, só é possível estudar quando há silêncio, nem todos respeitam o momento de estudo", sendo esse último adicionado por um dos estudantes no campo "Outros". Vinte futuros professores responderam essa pergunta. 


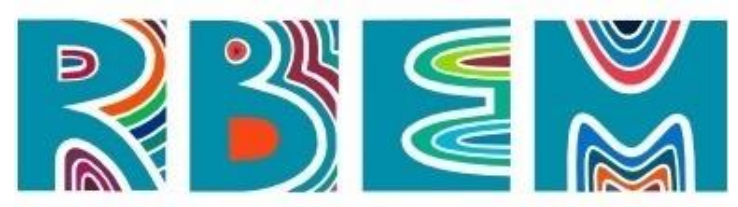

REVISTA BAIANA dE EDUCAÇÃo MATEMÁtica

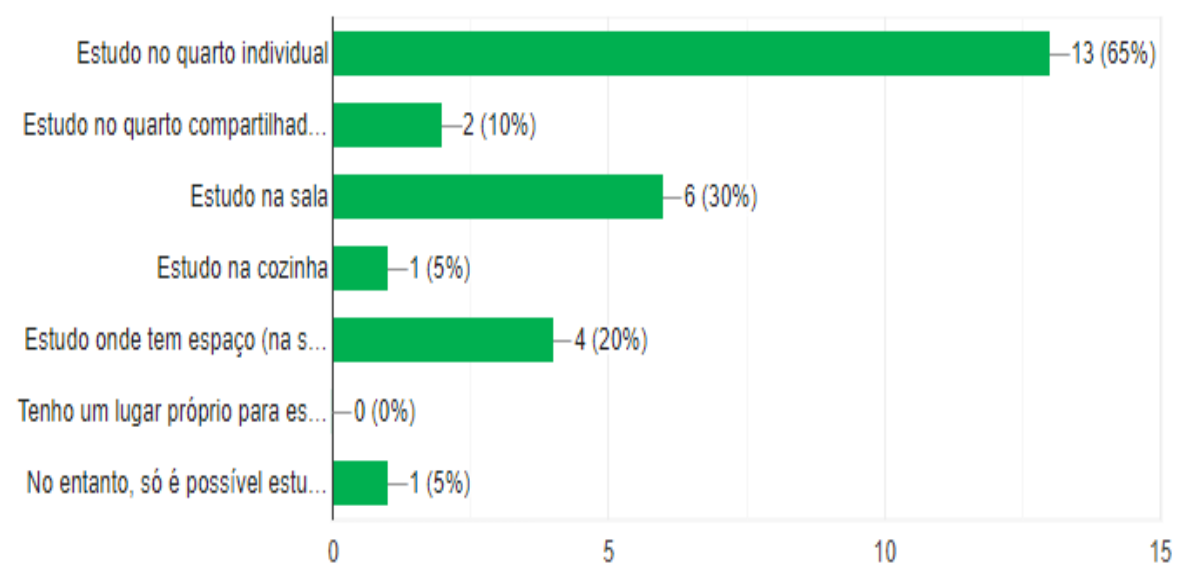

Gráfico 3 - Onde os futuros professores costumavam estudar na maior parte das vezes (ARQUIVO DOS

AUTORES, 2021)

Algumas questões instigavam os futuros professores a expressarem suas percepções quanto ao ensino remoto, o seu impacto nos estudos e como avaliavam a experiência de cursarem as disciplinas do curso de formação inicial em ERE. A questão aberta "Como está sendo a sua experiência com o ERE (na licenciatura) de maneira geral?" foi respondida por todos eles, a partir de entendimentos diversos sobre o momento vivido. As falas seguintes ilustram essas experiências.

*Tive alguns problemas com a falta de remanejamento do ensino remoto quanto à falta de empatia de alguns professores com o período que estamos passando, em vez de facilitar o ensino-aprendizagem, dificultaram ou mantiveram suas aulas no mesmo nível de dificuldade do ensino presencial. Outros passaram atividades de auxílio nas notas, o que ajudou muito (ESTAGIÁRIO 3, 2021).

*Degradante e desinteressante (ESTAGIÁRIO 6, 2021).

* Apesar de sentir falta do contato que o ensino presencial proporciona a maior parte do que eu fazia na UnB, eu consigo fazer em casa. E a grande vantagem do ensino remoto é a facilidade de conciliar a rotina. O simples fato de não precisar gastar mais 3 horas no transporte público faz valer a pena pra mim (ESTAGIÁRIO 9, 2021).

*Esses dois últimos semestres foram produtivos e consegui aproveitar e aprender muita coisa, mas sinto que falta o contato presencial, ainda mais nas matérias que vão às escolas para acompanhar os alunos de perto se faz necessário (ESTAGIÁRIA 12, 2021).

Igualmente, as respostas ao questionamento "Você sente que sua formação está sendo prejudicada?" mostrou entendimentos, também, divergentes. 


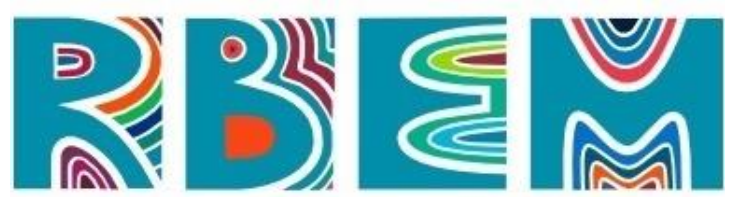

REVISTA BAIANA DE EDUCAÇÃO MATEMÁTICA

*Sim, especialmente no que tange o estágio, pois a relação professor/aluno fica muito comprometida à distância (ESTAGIÁRIO 6, 2021).

*Sim. Pois muitas matérias são difíceis de acompanhar online e passar várias horas em frente a um computador é extremamente cansativo (ESTAGIÁRIO 7, 2021).

*Sim. É difícil estudar a distância, principalmente, por não ter um espaço adequado de estudo (ESTAGIÁRIO 8, 2021).

*Acredito que não. Queria poder ter o contato direto com os alunos no estágio, testar meu domínio de turma presencialmente, mas eu aprendi muita coisa no ensino remoto que eu não aprenderia no presencial provavelmente. Como usar mesa digitalizadora, gravar vídeo aulas, elaborar questionários no forms, usar plataformas de gamificação (a exemplo do Quizizz e wordwall). Cada modalidade de ensino proporciona diferentes experiências, e todas são válidas (ESTAGIÁRIO 9, 2021).

A pergunta "Que materiais/recursos estão sendo usados nas suas aulas da licenciatura?" era de seleção e tinha como opções de resposta "Livros", "Apostilas", "Aulas gravadas", "Plataformas de sala online", "Redes sociais", "Aplicativos de troca de mensagens (por exemplo, WhatsApp)" e "Outro". Todos os estudantes responderam e alguns acrescentaram a opção "Materiais em PDF".

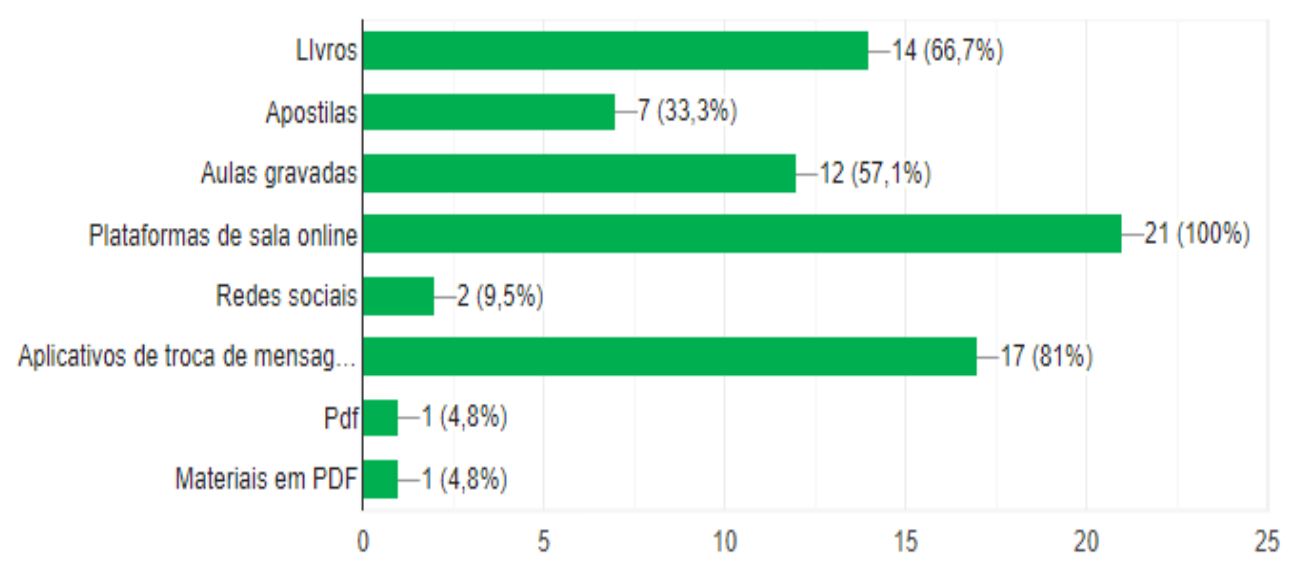

Gráfico 4 - Materiais/Recursos (ARQUIVO DOS AUTORES, 2021)

Também foi questionado se "Durante as aulas nas plataformas Google Meet, Zoom e outros, você preferiu?", com as seguintes opções de resposta: "Ficar com a câmera fechada durante a aula toda", "Ficar com a câmera fechada só durante a fala da professora ou dos colegas", "Ficar com a câmera aberta durante toda a aula", "Ficar com a câmera aberta somente quando avaliei necessário" e "Dependia do humor dos meus filhos, normalmente eles ficam correndo, pulando em mim, então na maior parte do tempo prefiro ficar com a câmera desligada.", sendo esse último adicionado por um dos estudantes no campo "Outros”. Essa 


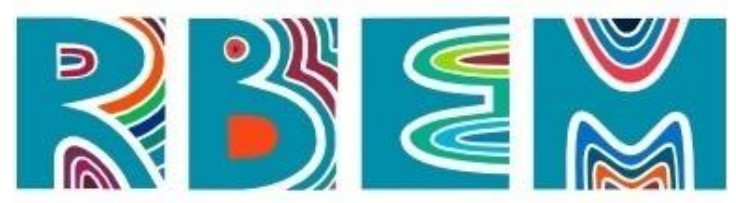

REVISTA BAIANA DE EDUCAÇÃO MATEMÁTICA

questão de caixa de seleção teve a penúltima opção mais selecionada, com 11 seleções, seguida da primeira com oito seleções.

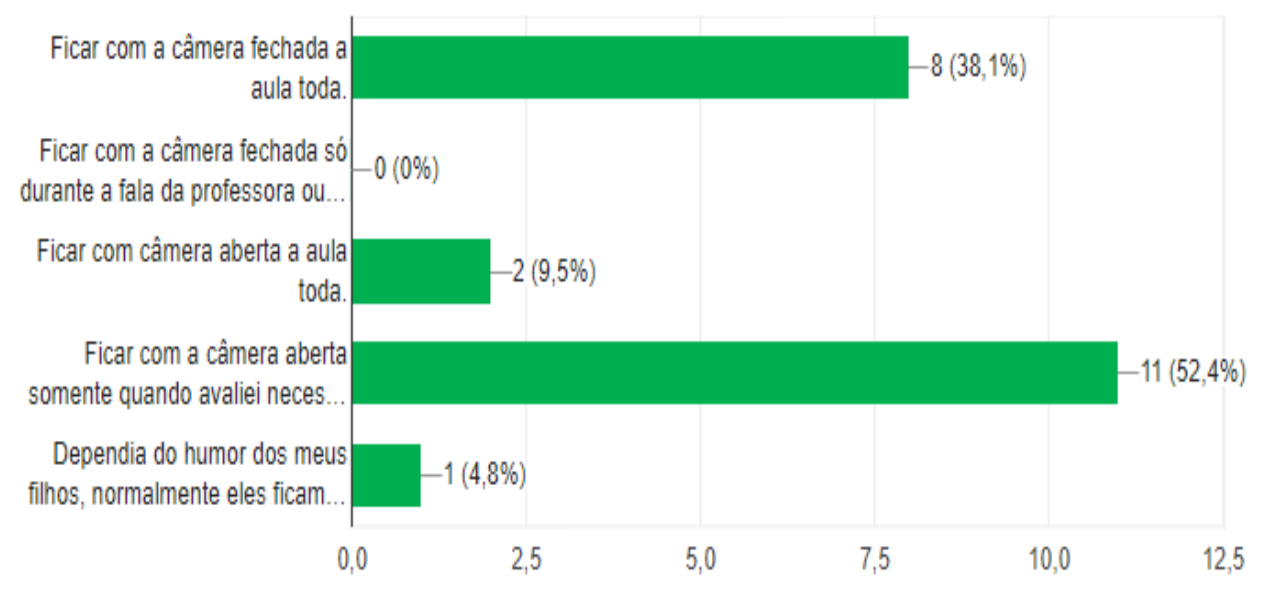

Gráfico 5 - Preferência dos estudantes (ARQUIVO DOS AUTORES, 2021)

De modo geral, os futuros professores foram unânimes em afirmar que conseguiram acessar a plataforma com desenvoltura, à exceção de um estudante que admitiu instabilidade de conexão. A percepção quanto ao ERE no tocante ao curso de licenciatura, de modo geral, diverge entre os futuros professores, enquanto alguns percebem o momento como de $\frac{14}{\text { B. BEVISTA }}$ (re)invenção e oportunidade para adquirirem habilidades em áreas não contempladas antes da pandemia, outros percebem o momento pelo viés da "ausência" - ausência de encontros presenciais entre os formadores e futuros professores; ausência de contato para o esclarecimento pontual de dúvidas; ausência de habilidades dos formadores em (re)inventar as próprias aulas frente às exigências do ERE, entre outras. Tudo isso, confirma como bem discutem Feitosa et al. (2020, p. 2), que "sair de um ensino presencial movido por uma interação física disponível e submeter-se ao ensino remoto é um desafio para alunos e professores".

\section{Percepções dos futuros professores quanto ao ECSM}

As falas dos futuros professores expressas nos relatórios finais de estágio destacam, de modo unânime, a necessidade de se construir planos de aula e ter o domínio do conteúdo que será ministrado. Para isso, eles avaliaram como fundamental ter conhecimento dos 


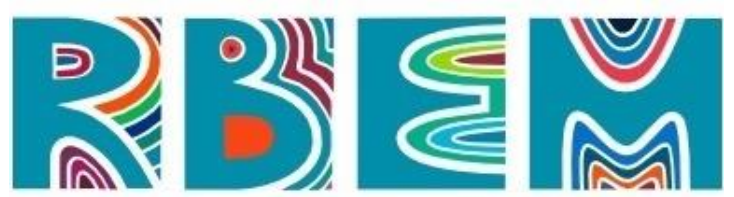

REVISTA BAIANA DE EDUCAÇÃO MATEMÁTICA

documentos oficiais que regem a modalidade de Ensino na qual se trabalha, valorizando/questionando a relação entre estes documentos e os projetos pedagógicos das escolas. Suas escritas revelam, igualmente, a necessidade do professor e do futuro professor conhecer o estudante, suas necessidades e realidade, estando sempre atentos a ela e a pluralidade dos jovens.

Para os futuros professores, o contexto do ERE causou, nos momentos iniciais, estranheza, mas, com o tempo aprenderam como é diferente e desafiador ministrar aulas online, para estudantes que não estão sentados em carteiras, mas atrás de telas, em suas casas, longe da supervisão e da interação presencial com os professores. Desse modo, constataram que na realidade do ERE um dos maiores desafios enfrentados pela professora supervisora foi o acompanhamento dos estudantes, visto que é necessária uma estrutura de acesso à internet com computadores ou celular, o que muitos estudantes da escola não tinham. Constataram, igualmente, que o vídeo amplia as possibilidades de tratamento dos conteúdos matemáticos podendo ser utilizado, na percepção deles, em momentos de abertura de um tópico curricular ou ao longo de seu tratamento.

No que tange à interação entre eles e professora orientadora, destacaram, positivamente, o modo como teoria e prática foram tratadas ao longo da disciplina de ECSM. Para eles, estudar e discutir aspectos da Base Nacional Comum Curricular, dos Novos Referenciais Curriculares, do Currículo em Movimento da SEEDF, da Matriz de Referência para o Exame Nacional do Ensino Médio (Enem) possibilitou melhor compreensão sobre o currículo e sua relação com a prática docente no ensino médio. Do mesmo modo, ressaltaram a importância do trabalhar em grupo adotado durante todo o ECSM, dos recursos utilizados pela professora orientadora, e do conteúdo teórico explorado como sustentação/reflexão/validação da aula planejada/ministrada.

*A disciplina de Regência 2 foi incrível. A professora, além de mostrar muita experiência e aprendizado, trouxe aulas leves e com participação que eu ainda não havia visto em outras disciplinas desde que as aulas passaram a ser remotas (ESTAGIÁRIO 1, 2021).

*O compartilhamento de recursos computacionais, promovido pela professora orientadora, se faz essencial, pois incentiva a adoção de novas ferramentas para o ensino que está mudando de forma acelerada (ESTAGIÁRIO 2, 2021). 


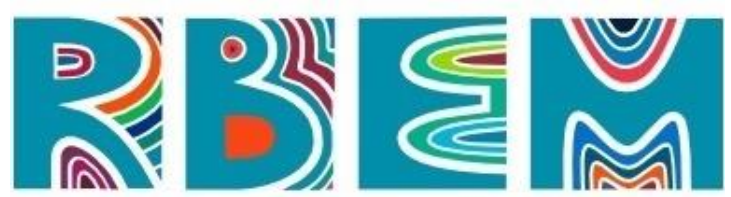

REVISTA BAIANA DE EDUCAÇÃO MATEMÁTICA

* O constante trabalho em grupo durante a disciplina gerou vários desafios e consequentes aprendizados (ESTAGIÁRIO 3, 2021).

*Quando nos foi apresentada a proposta de que o estágio seria feito em grupos e todos eles seriam supervisionados pela mesma professora, achei que não daria muito certo, porém me enganei completamente. $\mathrm{O}$ grupo foi um grande suporte durante toda a experiência, e sem ele não teríamos tido o êxito que alcançamos na produção e execução das atividades (ESTAGIÁRIO 4, 2021).

*De modo geral a experiência em criar e apresentar uma aula em grupo foi muito positiva, pois foi um conforto saber que se um integrante do grupo falhasse o outro estava para dar um suporte e se surgisse algum problema técnico outro integrante poderia corrigir essa falha (ESTAGIÁRIA 1, 2021).

*Estudar os conteúdos que iriam ser lecionados no momento da regência, a luz de documentos como BNCC e Currículo em Movimento do Distrito Federal, fez com que o planejamento fosse feito mais tranquilamente, pois tínhamos um norte (ESTAGIÁRIO 5, 2021).

Outro ponto destacado nos relatórios foi o estudo e a discussão realizada na disciplina a respeito da avaliação, compreendendo-a como um espaço para novos aprendizados.

O ponto da avaliação também foi essencial, compreender a avaliação não só como um mecanismo de definir notas, mas como algo que promove um retorno ao professor de como os seus estudantes estão em relação com os aprendizados e objetivos propostos na disciplina, passando também ao estudante que a avaliação é um momento de aprendizado também, em que ele pode identificar seus erros e dificuldades posteriormente aprendendo com eles (ESTAGIÁRIO 6, 2021).

Em várias passagens dos relatórios foi possível observar reflexões quanto á função da avaliação, quanto à necessidade de o professor avaliar também suas práticas. Falas que se aproximam das defesas já postas por Buriasco (1999, p. 72):

[...] definir princípios em função de objetivos que se pretendem alcançar; estabelecer instrumentos para a ação e escolher caminhos para essa ação; verificar constantemente a caminhada, de forma crítica, levando em conta todos os elementos envolvidos no processo. Sendo assim, ela não possui uma finalidade em si, mas sim subsidia o curso de uma ação que visa construir um resultado previamente definido (BURIASCO, 1999, p. 72).

Em alguns relatos os futuros professores registraram que antes da experiência em ECSM, especialmente em relação ao plano de ensino, basicamente pensavam que "lecionar uma aula era somente passar o conteúdo, explicar com exemplos e exercícios e nunca tinham pensado a respeito das possíveis dúvidas dos alunos" (ESTAGIÁRIO 8, 2021). Dessa forma, 


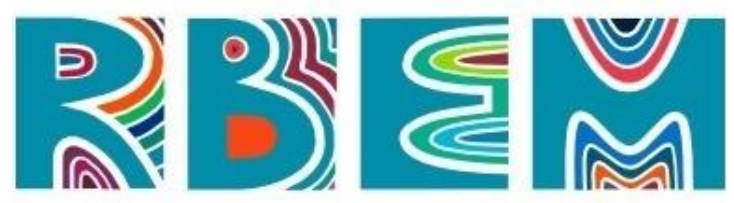

REVISTA BAIANA DE EDUCAÇÃO MATEMÁTICA

ressaltaram que o estudo sobre o planejamento agregou bastante em suas formações para a docência. Além disso, perceberam que não é recomendado que o professor entregue todas as respostas facilmente durante a resolução de problemas para os alunos, que o professor precisa dar a chance para o aluno criar suas próprias hipóteses.

*O plano de aula achava que era um capricho ou formalidade para os educadores, mas percebi que é algo extremamente relevante para o sucesso de uma aula. Por fim, antes qualquer atividade matemática seja um exercício ou questão, classificava entre menor ou maior a dificuldade de uma resolução, mas aprendi que tem uma diferença entre um exercício, problema e atividade de investigação (ESTAGIÁRIO 8, 2021).

*O trabalho do professor é sério e vai além da sala de aula. Passa por planejamento, disciplina e atividade domiciliar, e, claro, formação de cidadãos. Este trabalho torna-se mais simples quando há um plano de aula dinâmico que prevê as ações dos alunos (ESTAGIÁRIA 4, 2021).

*O plano de aula é de suma importância porque explicita o que são os objetivos da aula, como serão atingidos e em quanto tempo. Ele funciona como um guia, uma rota que orienta o professor sobre seus objetivos e abre um leque de opções criativas a fim de serem alcançadas. (ESTAGIÁRIO, $10)$.

*Essa experiência aconteceu de forma conjunta, o que facilitou ainda mais esse estudo, tanto na parte teórica quanto na parte prática, e um dos momentos mais fundamental foi dentro da sala de aula online de forma síncrona, tive a oportunidade de realizar uma aula. Aprendi que ter um bom planejamento de aula ajuda bastante para uma boa aula, ainda mais se ocorre algum imprevisto durante a realização da aula, e antecipar as possíveis dúvidas dos alunos é fundamental (ESTAGIÁRIO 11, 2021).

No que se refere à interação com a professora supervisora e ao estágio na referida escola eles registraram que por meio da observação de suas aulas e diálogos concluíram que o trabalho do professor vai além da sala de aula. Constataram que os docentes no desafio de se adaptarem ao ensino remoto, passaram a trabalhar mais do que se estavam acostumados. Segundo eles, a professora supervisora relatou o esforço dos colegas professores em sua escola para incluir alunos com dificuldades financeiras, sejam alunos que necessitavam estudar o dia todo e não possuíam condições financeiras para almoçar, quando era ensino presencial, sejam os alunos que recebem material didático em casa.

Afirmaram que por se tratar de aulas remotas não tiveram a oportunidade conhecer a estrutura da escola, mas, tiveram contato com a professora supervisora e uma intérprete de libras que por vezes interpretava as falas da professora supervisora, por meio de uma chamada de vídeo. Destacaram a dedicação da professora supervisora em resolver os problemas que 


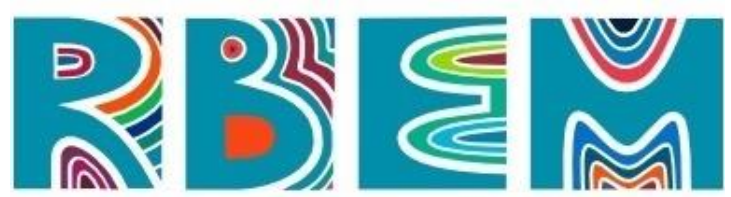

REVISTA BAIANA DE EDUCAÇÃO MATEMÁTICA

surgiam durante as aulas, em contextualizar as aulas, responder as dúvidas dos alunos e oferecer um ensino de matemática de qualidade.

*Independente das falhas técnicas como problemas de conexão a professora sempre se esforçava para realizar todas as aulas e também a maneira como ela lidou com participações inapropriadas de alunos (ESTAGIÁRIO 12, 2021).

*Desde a primeira aula, uma característica marcante da professora foi de começar suas aulas com temas contemporâneos, seja comentando as notícias mais recentes ou trazendo elementos culturais para a introdução da aula (ESTAGIÁRIO 13, 2021).

* Observando a professora regente em ação, aprendemos a importância de se estabelecer um diálogo com os alunos além da matemática. A professora utiliza artifícios para atrair os alunos, buscando trazer assuntos da atualidade de maneira interdisciplinar. Ela também nos mostrou como lidar bem com situações imprevistas (ESTAGIÁRIO 14, 2021).

*Falando em relação à professa regente, fico muito feliz de ter tido a experiência de regência com uma professora tão comprometida e tão apaixonada pela educação, o carinho com os alunos e calma durante as explicações, a matemática colocada em situações do dia-a-dia isso e muito mais são práticas recorrentes de todas as aulas da professora (ESTAGIÁRIO, $15)$.

Os estagiários afirmavam que tiveram surpresas durante a passagem pela escola, como a participação dos alunos, pois, achavam que fosse bem maior do que de fato era. Outra surpresa foi a professora supervisora que mesmo estando prestes a se aposentar, se reinventou para conseguir oferecer um ensino de qualidade aos seus alunos na realidade do ERE. Não utilizava muitos recursos tecnológicos ou metodologias diferentes, mas se dedica para fazer um trabalho de qualidade e isso foi notório em suas aulas. Eles relataram, ainda, que perceberam na professora supervisora muito "amor" pela educação, muito comprometimento, o que comprova que mesmo na adversidade, a educação pode ser feita com qualidade.

Apesar da baixa participação dos alunos nas aulas, os futuros professroes observaram que eles fizeram do "chat seu lugar de fala" (ESTAGIÁRIO 7, 2021). Nesse espaço eles "expressavam dúvidas e comentários sobre o conteúdo proposto" (ESTAGIÁRIO 9, 2021) e conversaram sobre assuntos do interesse deles. Tudo isso mostrou aos envolvidos no ECSM que a moderação do chat deve ser bem considerada no planejamento das aulas, em especial, para situações não relativas ao conteúdo. Além desses aspectos já mencionados, os relatórios mostraram também, como a tecnologia pode falhar e tumultuar a aula. Imprevistos técnicos com a própria internet, com os aparelhos tecnológicos utilizados nas aulas como 


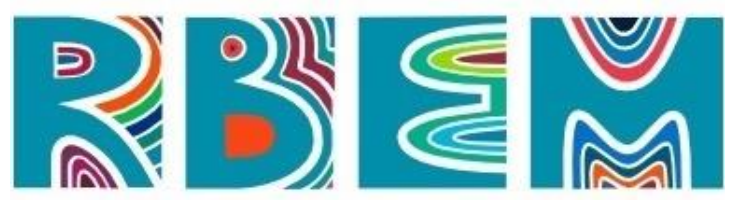

REVISTA BAIANA DE EDUCAÇÃO MATEMÁTICA

Smarthphone, Tablet e computadores influenciou a continuidade da aula tanto por parte da professora supervisora, dos futuros professores e dos alunos.

Em relação às percepções sobre o futuro como professores, eles destacaram o trabalho em grupo, a oportunidade de observar o trabalho de uma professora experiente e feliz com a profissão, a importância do diálogo no processo de ensino e aprendizagem e o significado da contextualização do ensino.

\begin{abstract}
* Observar um professor experiente foi algo que agregou muito, em questões de como lidar com os alunos, como estruturar as aulas de uma forma, como se adaptar num contexto diferente do normal e como lidar com as adversidades em sala de aula de forma inteligente (ESTAGIÁRIO 5, 2021, grifo nosso).

*A educação é algo que não se constrói sozinho. O diálogo entre as pessoas envolvidas com ações educacionais é de primordial importância para uma prática educativa com sentido e clara para todos e todas (ESTAGIÁRIO 11, 2021, grifo nosso).

*As discussões no que tange as aulas possibilitaram ao grupo diagnosticar um tema ou um problema a partir de uma situação real, procurar uma solução para tentar transformar aquela realidade e educando e fazendo aquilo que for preciso. A dificuldade de diálogo nas aulas que aconteciam na modalidade presencial, também acontece em um contexto remoto (ESTAGIÁRIO 13, 2021, grifo nosso).

*Em minha opinião não se trata da quantidade de conteúdos que são abordados, mas sim da qualidade com que eles são apresentados. De fato, trabalhar qualquer que seja o assunto sem uma contextualização, ou sem uma aplicação prática é algo que se tornara frustrante para um aluno que não possui tanto interesse no conteúdo de matemática (ESTAGIÁRIO 16, 2021, grifo nosso).
\end{abstract}

Outros pontos destacados pelos futuros professores foram em relação ao trabalho do professor na realidade do ERE, da revolução com a introdução das novas tecnologias (na comunidade escolar) e de como o futuro professor precisa estar atendo a essa nova realidade.

*O trabalho do professor durante esse período pandêmico aumentou significativamente. Primeiro, teve que se adaptar a um novo modo de ensinar de uma hora para hora. Depois, começar a usar novas ferramentas como mesa digitalizadora ou tablet para servir de quadro. Mudar a forma como a aula era ministrada e ainda se preocupar em criar material o mais completo e abrangente possível de material escrito para atender os alunos que não participam das aulas por videoconferência (ESTAGIÁRIA 2, 2021).

*A escola estava passando por um momento de revolução com a introdução das novas tecnologias. Entretanto, com a pandemia mundial, esse processo foi acelerado. Saindo do ensino presencial para o ensino totalmente remoto. 


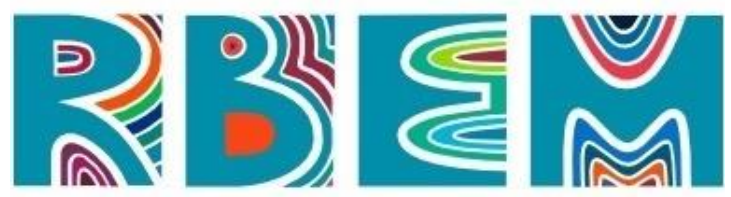

REVISTA BAIANA DE EDUCAÇÃO MATEMÁTICA

A mudança brusca mostrou como estamos em estágios diferentes e como temos diferenças na nossa sociedade. Acredito que a escola do futuro será um misto entre o tradicional presencial e o ensino a distância (ESTAGIÁRIO 8, 2021).

*O professor do futuro tem que estar apto a agregar novas tecnologias para preparar as suas aulas. Mesmo voltando para o ensino presencial, algumas ferramentas usadas durante o EAD serão de grande valor (ESTAGIÁRIO 6, 2021).

Destacaram, igualmente, o valor de conhecerem várias ferramentas e plataformas que podem ser usadas para tornar as aulas mais interativas, interessantes e simples. Analisaram que este conhecimento será vital para a atuação profissional seja em situações de ensino remoto, hibrido ou presencial.

*Nomes como Kahoot!, Mentimeter, Wordwall, Quizziz e tantos outros se tornaram comuns para mim e tantos outros professores e alunos. Eu realmente acredito que estas são ferramentas fantásticas que farão parte do futuro da nossa educação cada vez mais (ESTAGIÁRIO 2, 2021, grifo nosso).

*Aprender a utilizar os recursos digitais e tornar suas aulas cativantes, será um recurso fundamental para os professores futuros professores, pois apesar de estarmos vivenciando uma situação atípica, esse problema acelerou a progressão de várias atividades aos meios virtuais, apesar de possuir seus desafios a educação a distância é uma dessas atividades (ESTAGIÁRIO 3, 2021, grifo nosso).

*É importante ressaltar o nosso papel como professor de compreender o público alvo com o qual trabalhamos e sempre adaptarmos nossas aulas à realidade dele e entendermos também a respeito da pluralidade dos jovens (ESTAGIÁRIO 4, 2021, grifo nosso).

*Foi possível conhecer novas estratégias de ensino atreladas ao uso da tecnologia, entendemos o funcionamento das aulas síncronas e assíncronas, tivemos contato com o ambiente Google Classroom e observamos a interação entre os alunos e a professora ao longo dos meses (ESTAGIÁRIO 7, 2021, grifo nosso).

*Acerca da minha experiência pessoal, mesmo com a falta do contato presencial, fui muito feliz no estágio. As aulas remotas são um desafio constante e, com isso, nelas eu aprendi coisas que eu não sei se aprenderia no estágio presencial, como fazer apresentações dinâmicas no Prezżi e utilizar plataformas de gamificação como o Quizizz (ESTAGIÁRIO 9, 2021, grifo nosso).

Os estagiários reconheceram que a "Regência" é essencial para a formação do futuro professor no contexto de licenciatura. Embora, tenham vivenciado um momento atípico com a pandemia, e os períodos de observação, coparticipação e regência terem sido realizados de 


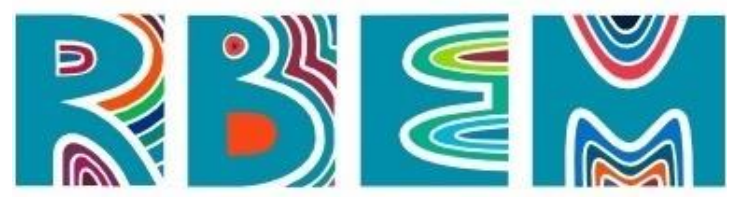

REVISTA BAIANA DE EDUCAÇÃO MATEMÁTICA

maneira remota, e por essa razão, não terem conhecido as dependências da escola, nem a professora supervisora e os alunos pessoalmente, avaliaram que a experiência do estágio foi muito agregadora e significativa para o futuro de cada um deles como professor.

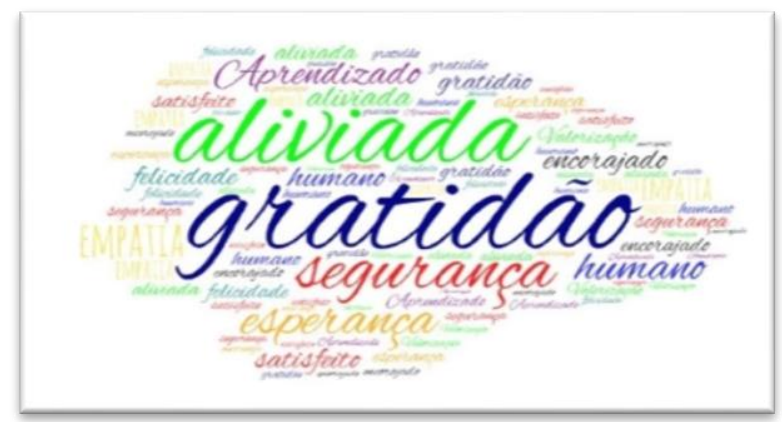

Figura 2: Nuvens de palavras 1 (ARQUIVO DAS AUTORAS, 2021).

* Me sinto com muita sorte de ter tido a oportunidade de participar de uma regência tão engrandecedora como esse que me fez evoluir e abrir caminhos para métodos educacionais que antes eu não tinha a visão. A palavra que descreve meu sentimento é gratidão! (ESTAGIÁRIA 4, 2021). foi uma experiência muito enriquecedora que no preparados para a vida como educadores e nos trouxe muitos aprendizados para serem aplicados no futuro (ESTAGIÁRIO 11, 2021).

*Em suma, foi bastante pertinente para minha formação essa experiência em um momento tão novo, no qual a educação mundial se encontra (ESTAGIÁRIO, 14).

Por fim, foi possível observar que a percepção dos futuros professores sobre o ECSM alterou, significativamente, do início da disciplina para o final, como mostram as imagens seguintes.

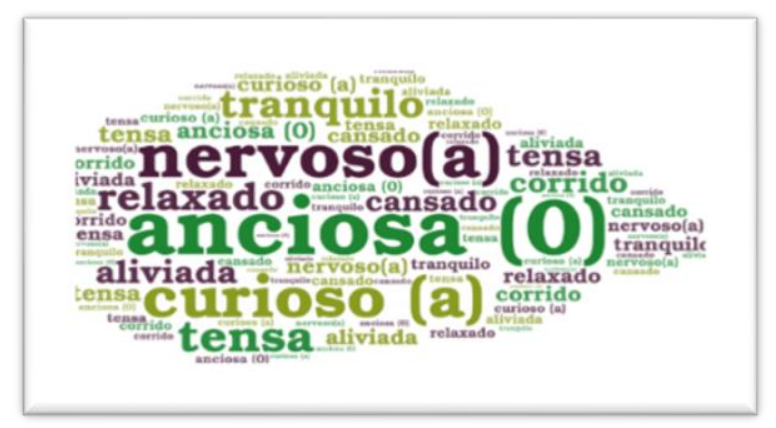

Figura 3: Nuvens de palavras 2 (ARQUIVO DAS AUTORAS, 2021). 


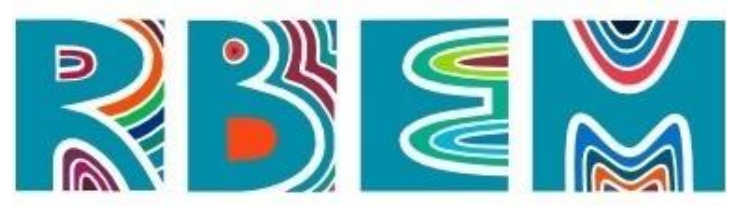

REVISTA BAIANA DE EDUCAÇÃO MATEMÁTICA

Entendemos, assim, que o ECSM tem se constituído em importante espaço formativo com fortes vínculos entre a universidade/escola e ampla interação entre professores orientadores, supervisores e futuros professores, configurando-se em espaço de reinvenção, transformação, constantes. "Deixo o estágio orgulhoso do resultado e com vontade de aprender mais" (ESTAGIÁRIO, 15, 2021).

\section{Considerações finais}

De modo geral, os resultados ajudam-nos a compreender vários aspectos do ECSM no que se refere à sua oferta em situação de ERE, ao seu desenvolvimento e, de modo especial, as aprendizagens que a experiência possibilitou a todos os envolvidos. Vivenciar o ECSM em ERE ampliou a compreensão dos futuros professores sobre os desafios que os docentes têm enfrentado como: dificuldades de acesso à internet e à equipamentos; limitações de formação para o uso das tecnologias da informação e comunicação; limitações de formação para o desenvolvimento de aulas não presenciais que sejam pertinentes aos tópicos curriculares abordados, aos estudantes atendidos. De modo especial, eles compreenderam os riscos do ERE excluir estudantes, professores e futuros professores. Aprenderam que é preciso garantir equidade, inclusão por meio de ações institucionais e de políticas públicas.

A incerteza do momento atual fez com todos percebessem o valor da mudança, de estar preparado para ela, de produzir mudança ao mesmo tempo em que comprovaram os riscos de serem somente usuários acríticos de conhecimento, de perpetuarem uma educação por meio da transmissão de conteúdos. A necessidade de criar, validar, aperfeiçoar, reinventar e transformar a realidade social fez com eles valorizassem, fortemente, a experiência que vivenciaram. O fato de cursarem o ECSM em ERE com espaço para estudo, planejamento, socialização, replanejamento de modo coletivo, tendo os futuros professores espaço de fala e escrita sendo estes valorizados, incentivados - possibilitou autoria coletiva dos grupos e da equipe que integrou a disciplina. Desse modo, eles mostraram "[...] a apropriação do valor teórico da profissão; o despertar de um senso crítico no planejamento de aulas; abertura para o trabalho com os pares; o desenvolvimento de uma atitude de pesquisa" (TEIXEIRA; CYRINO, 2015, p. 658). 


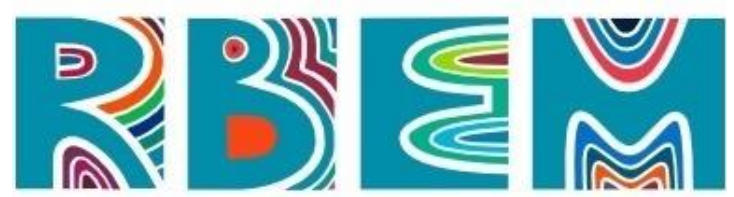

REVISTA BAIANA DE EDUCAÇÃO MATEMÁTICA

Tudo isso mostra-nos, igualmente, que experiências dessa natureza ajudam-nos a refletir sobre como o ERE impulsionou discussões, necessidades e busca de alternativas que muito contribuem para o desenvolvimento da Educação a Distância no Brasil, fomentando inclusive avanços quanto á melhor definição do papel da avaliação nesses contextos não presenciais de ensino e de aprendizagem (PRETTO; BONILLA; SENA; 2020).

\section{Referências}

BARBOSA, C.P.; LOPES, C. E. Uma análise da produção acadêmica brasileira sobre o Estágio Curricular Supervisionado nos cursos de Licenciatura em Matemática. Revista de Educação Matemática, São Paulo, v. 18, 2021, pp. 1-23 - e021014.

BARDIN, L. Análise de Conteúdo. Lisboa: Edições 70, 3ª reimp., 2016.

BRAGA, M. D.; MENEZES, J. E.; SEIMETZ, R..; SILVA, P. M; SILVA, S. A. Um Estudo Comparativo sobre as Impressões de Alunos das Licenciaturas no Ensino Remoto em Duas Universidades Públicas. Perspectivas da Educação Matemática, v. 14, n. 34, p. 1-19, 12 abr. 2021.

BURIASCO, R. L. C. Avaliação em Matemática: um estudo das respostas dos alunos e professores. 238 f. Tese (Doutorado em Educação) - Universidade Estadual Paulista, Programa de Pós-Graduação em Educação da Universidade Estadual Paulista, Marília, 1999.

DAUANNY, E. B; LIMA, M. S. L; PIMENTA, S. G. Produção teórico-prática sobre o estágio na formação do professor - uma revisão crítica. Revista Interdisciplinar Sulear, Ano 1, n. 3, nov. 2019.

DINIZ PEREIRA, J. E. Formação de professores, trabalho docente e suas repercussões na escola e na sala de aula. Educação \& Linguagem, São Paulo: Universidade Metodista de São Paulo, ano 10, n. 15, p. 82-98, jan./jun. 2007.

FEITOSA, M.C.; MOURA, P.S.; RAMOS, M.S. F.; LAVOR, O. P. Ensino Remoto: O que Pensam os Alunos e Professores? In: Congresso sobre Tecnologias na Educação $(C T R L+E)$, 2020, Evento Online. Porto Alegre: Sociedade Brasileira de Computação, 2020. p. 60-68.

FIORENTINI, D.; CASTRO, F. C. de. Tornando-se professor de matemática: o caso de Allan em prática de ensino e estágio supervisionado. In: FIORENTINI, Dario (org.). Formação de professores de matemática: explorando novos caminhos com outros olhares. Campinas, SP: Mercado de Letras, 2003.p. 121- 156.

FRANCO, M.L.P. B. Análise de conteúdo. 5 ed. Brasília: Liber Livro, 2018. 


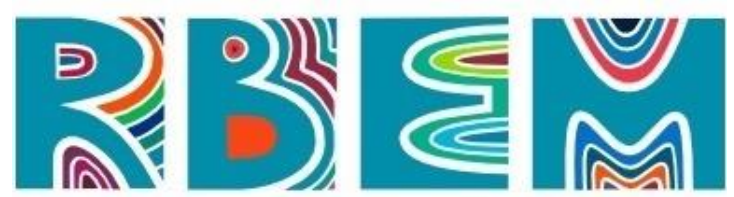

REVISTA BAIANA DE EDUCAÇÃO MATEMÁTICA

GATTI, B. A. Formação inicial de professores para a educação básica: pesquisas e políticas educacionais. Estudos em Avaliação Educacional. v. 25, n. 57, p. 24 - 54, 2014.

GATTI, B.A.; BARRETO, E.S.S. Professores: aspectos de sua profissionalização, formação e valorização social. Brasília, DF: UNESCO, 2009.

GIL, A. C. Métodos e técnicas de pesquisa social. $7^{\text {a }}$ ed. São Paulo: Atlas, 2019.

LOPES, A. R. L. V.; PAIVA, M. A. V.; POZEBON, S.; CEDRO, W. L. Estágio Curricular Supervisionado nas licenciaturas em Matemática: reflexões sobre as pesquisas brasileiras. Zetetiké, Campinas, SP, v. 25, n. 1, p. 75-93, jan./abr. 2017.

MOREIRA, J. A. M.; HENRIQUES, S.; BARROS, D. Transitando de um ensino remoto emergencial para uma educação digital em rede, em tempos de pandemia. Dialogia, São Paulo, n. 34, p. 351-364, jan./abr. 2020. Disponível em: https://doi.org/10.5585/Dialogia.N34.17123.

MELGAREJO VARGAS, L. M. Sobre el concepto de percepción. Alteridades, vol. 4, núm. 8, 1994, pp. 47-53

PIMENTA, S. G; LIMA, M. S. L. Estágio e docência. São Paulo: Cortez, 2012.

PONTE, J. P., BRANCO, N., QUARESMA, M. Exploratory activity in the mathematics classroom. In Y. Li, E. Silver \& S. Li (Eds.), Transforming mathematics instruction: Multiple approaches and practices, Dordrecht: Springer Science+Business. Media Dordrecht, 2014, p. 103- 125.

PRETTO, N.; BONILLA, M. H.; SENA, I. Educação em tempos de pandemia: reflexões sobre as implicações do isolamento físico imposto pela COVID-19. Salvador: Edição do Autor, 2020.

PROENÇA, M. C. Licenciando em matemática na regência de aula: análise de saberes docentes a partir da avaliação de professores tutores tutores1. Educação Matemática. v.14, n.1, pp.85-103, 2012. Disponível em: https://revistas.pucsp.br/ emp/article/view/5911/6830. Acessado em: 28 de maio 2019.

RICHARDSON, R. J.; PERES, J. A. S. et al. Pesquisa social: método e técnicas. 4 ed. São Paulo: Atlas, 2017.

TEIXEIRA, B.R.; CYRINO, M.C.C.T. Desenvolvimento da Identidade Profissional de Futuros Professores de Matemática no Âmbito da Orientação de Estágio, Bolema: Boletim de Educação Matemática (Online), v. 29, p. 658-680, 2015.

TEIXEIRA, B. R. CYRINO, M. C. C. T. O estágio supervisionado em cursos de Licenciatura em Matemática: um panorama de pesquisas brasileiras. Educação Matemática. v.15, n.1, pp.29-49, 2013. 


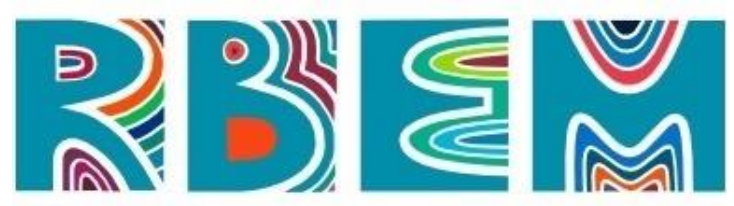

Artigo submetido em: 30/07/2021

Artigo aceito em: 05/11/2021 